\title{
Colony site choice of blue-tailed bee-eaters: influences of soil, vegetation, and water quality
}

\author{
HSIAO-WEI YUAN ${ }^{1}$, D. BRENT BURT ${ }^{2}$, LEE-PING WANG ${ }^{1}$,

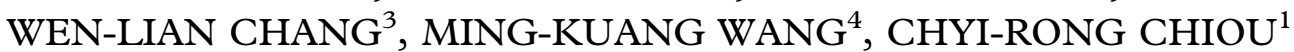 \\ \& TZUNG-SU DING ${ }^{1}$
}

${ }^{1}$ School of Forestry and Resource Conservation, National Taiwan University, Taipei, Taiwan, ${ }^{2}$ Department of Biology, Stephen F. Austin State University, Nacogdoches, Texas, USA, ${ }^{3}$ Department of Bioenvironmental Systems Engineering, National Taiwan University, Taipei, Taiwan, and ${ }^{4}$ Department of Agricultural Chemistry, National Taiwan University, Taipei, Taiwan

(Accepted 3 March 2006)

\begin{abstract}
All bee-eaters (Family Meropidae) are cavity nesters, excavating terrestrial burrows in sites ranging from flat ground, to small mounds of soil, steep earthen banks seen in road clearings, eroded cliff faces, and river gorges. However, very little is known concerning the environmental factors that influence nest site selection in bee-eaters. We addressed abiotic and biotic issues associated with colony site choice in blue-tailed bee-eaters (Merops philippinus) nesting on Kinmen Island, off mainland China, from 2000 to 2002 . About $89 \%$ of the colonies were located on slopes with soils of sandy loam and the other $11 \%$ on sandy clay loam. No colony was found on clay loam, which covered $20 \%$ of the island. The sandy loam and sandy clay loam had lower soil pressure, density and moisture, which, presumably, were easier for bee-eaters to excavate and provided better drainage and ventilation for nest cavities. Bee-eaters avoided placing nest cavities in areas with dense vegetation and abandoned colony sites when they became overgrown. Vegetation would impede excavation and decrease the detectability of predators. Bee-eaters may prefer colony sites near water bodies showing water chemistries indicative of more biological productivity, especially in relation to the diversity and abundance of their major prey, dragonflies.
\end{abstract}

Keywords: Blue-tailed bee-eaters, breeding ecology, colonial breeding, habitat selection

\section{Introduction}

The study of habitat selection in birds has long received attention (Grinnell 1917; Kendeigh 1945; Fretwell and Lucas 1970; Block and Brennan 1993; Jones 2001). Habitat selection may take place at several spatial scales, from microhabitat to geographic range (Johnson 1980; Morris 1987; Orians and Wittenberger 1991). Nest site choice influences

Correspondence: Tzung-Su Ding, School of Forestry and Resource Conservation, National Taiwan University, Taipei, Taiwan. Email: ding@ntu.edu.tw

Published 12 June 2006

ISSN 0022-2933 print/ISSN 1464-5262 online (C) 2006 Taylor \& Francis DOI: $10.1080 / 00222930600681043$ 
the likelihood of successful reproduction due to both abiotic environmental factors (Block and Brennan 1993) and biotic factors such as nest predation (Martin 1993), competition (Martin 1993; Petit and Petit 1996), intraspecific attraction (Danchin et al. 1998; Forsman et al. 1998), and food limitation (Martin 1993; McCollin 1998).

Blue-tailed bee-eaters (Merops philippinus Linnaeus) are migratory breeders on Kinmen Island, an islet $5 \mathrm{~km}$ off mainland China. Very few studies have reported on the general ecology of this species (Fry 2001; Burt 2002). These aerial insectivores arrive on breeding grounds in April and can be seen foraging frequently in agricultural fields and grasslands bordering sandy beaches. Over $75 \%$ of their prey items come from the insect orders (in order of importance) Odonata, Hymenoptera, and Lepidoptera (Wang 2003). Blue-tailed bee-eaters are socially monogamous with helpers in attendance at some nests (Burt 2002; Wang 2003).

The bee-eaters begin excavating nest cavities in May. While some breeding pairs nest solitarily, the majority of individuals nest in colonies that range in size from as few as three to as many as 100 breeding pairs. Nesting colonies are often found in beach sand dunes, construction site sand piles, and sand piles created by farm pond excavations so colonies are not infrequently associated with freshwater ponds.

Other Merops bee-eater species have been described as nesting on the ground or along river banks and cliffs with clear or sparse vegetation (White et al. 1978; Emlen 1990; Kossenko and Fry 1998; Boland 2004). However, there was no detailed study on these species' breeding habitat selection. In this study we addressed abiotic and biotic issues associated with colony site choice in blue-tailed bee-eaters. First, we examined the distribution of colonies as it relates to the major soil and habitat types on Kinmen Island. Second, we documented the differences in soil properties of colony sites and sites not used by bee-eaters. Third, we investigated how vegetation structure at colonies influences colony establishment and abandonment. Finally, we examined the differences in water chemistry between ponds associated with and without bee-eater colonies. We documented how water chemistry differences appear to influence dragonfly abundance and diversity associated with these ponds.

\section{Methods}

\section{Study sites and duration of study}

We conducted this study from April to October 2000-2002 on Kinmen Island (118 8$21^{\prime} \mathrm{E}, 24^{\circ} 22-34^{\prime} \mathrm{N}, 13,425 \mathrm{ha}$ ). Through interviews with residents and intensive surveys at the beginning of each breeding season, we identified 21 bee-eater colonies that were active during at least one of the study years (Figure 1). We also located two abandoned colonies ( $\mathrm{G}$ and $\mathrm{H}$ ) that had last been active in 1998 . For each site we recorded the colony location, the number of bee-eaters, and the number of active nest cavities. The number of bee-eaters at each colony in 2002 was estimated by counting the number of individuals perched on or near the colony on several days and represents a conservative estimate. We compared the distribution of active 2002 colony sites among the major habitat types as well as the three main soil types of Kinmen Island: clay loam (20\%), sandy clay loam $(<2 \%)$, and sandy loam (78\%) (Kuo and Chen 2002).

\section{Soil sampling and testing}

We collected soil samples from three locations representing each soil type: D, G, H (sandy clay loam); A, W, X (sandy loam); and E, J, R (clay loam). We collected approximately 


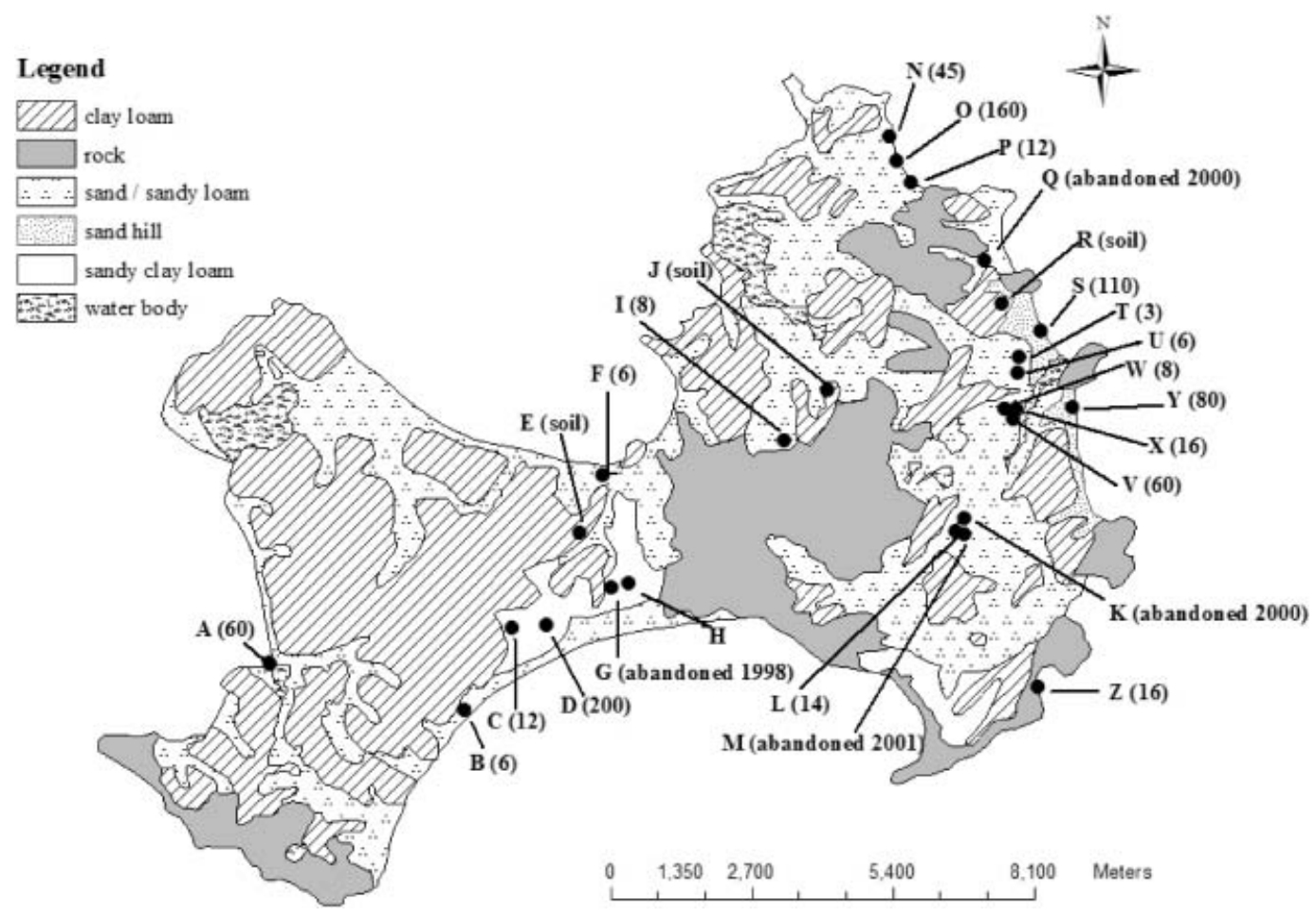

Figure 1. Distribution of blue-tailed bee-eater colony and soil sampling sites on Kinmen Island 2000-2002. Population estimates are given in parentheses for colonies active in 2002.

$500 \mathrm{~g}$ of soil near nest cavities (sandy loam and sandy clay loam) and at random places (clay loam) at a depth of $30 \mathrm{~cm}$. Samples were sealed in two layers of plastic bags and transported to the laboratory for further analysis. We conducted the following tests on each sample: density $\left(\mathrm{g} \mathrm{cm}^{-3}\right)$, moisture (\%), and $\mathrm{pH}$. Additionally, a pentrometer was used to measure soil pressure $\left(\mathrm{g} \mathrm{cm}^{-3}\right)$ in 10 locations at $\mathrm{D}, \mathrm{G}, \mathrm{H}$ (sandy clay loam); 20 locations at $\mathrm{A}, \mathrm{K}$, W, X (sandy loam); and five locations at E, J, R (clay loam). Each location was at least $10 \mathrm{~m}$ apart. Kruskal-Wallis tests were used to compare the differences of soil compositions among different soil types and Dunn multiple comparisons were used for pair-wise comparisons.

\section{Vegetation sampling}

In 2002, we measured vegetation height for all plants encountered every $0.5 \mathrm{~m}$ along $5-\mathrm{m}$ transects extending from the front of both active nesting cavities and cavities used in previous years. In one comparison, active $(n=10)$ and old $(n=13)$ cavities were located in different sections of the same colony (X). In another comparison, active cavities $(n=3)$ were located in a newly established colony $(\mathrm{L})$ while old cavities $(n=13)$ were located in a nearby colony (M) abandoned after the 2001 breeding season. We used Mann-Whitney $U$ tests to investigate vegetation differences in front of abandoned and active nest cavities in these two comparisons.

In another analysis, we used a photograph of one colony (Y) and selected 20 random nesting cavities and 20 random points. We then measured the distance from each cavity or 
random point to its nearest vegetation. A $t$ test was used to test the prediction that cavities would be located further from vegetation than random points.

\section{Water chemistry and dragonfly diversity}

Dragonflies are a major food source for bee-eaters on Kinmen Island. We speculated that water chemistry would affect dragonfly larva abundance, which in turn might influence colony site selection by bee-eaters. We selected colony sites in 2002 with ponds nearby to test for differences in water chemistry between active colony sites (L, W, X, V) and sites that have been abandoned for at least 5 years $(\mathrm{G}, \mathrm{H})$. We recorded the following data in the field: water temperature $\left({ }^{\circ} \mathrm{C}\right), \mathrm{pH}$, electric conductivity (EC), dissolved oxygen (DO), and turbidity (NTU). Water samples were collected in 1-litre plastic containers and taken to the laboratory for the following chemical analyses: biological oxygen demand $\left(\mathrm{BO}_{5}\right)$, and dissolved ions $\left(\mathrm{NO}_{3}{ }^{-}-\mathrm{N}, \mathrm{Cl}^{-}, \mathrm{SO}_{4}{ }^{2-}, \mathrm{NH}_{4}{ }^{+}, \mathrm{HCO}_{3}{ }^{-}, \mathrm{Ca}, \mathrm{Mg}, \mathrm{Na}, \mathrm{K}\right.$, and chlorophyll $a$ ).

Additionally, from April to August 2002, we surveyed dragonfly species at these six sites. We visited each site twice per month, only on sunny and calm days when temperatures were between 25 and $35^{\circ} \mathrm{C}$, and scanned the pond twice for $10 \mathrm{~min}$. Dragonfly species and number were recorded. We ranked total dragonfly abundance from 0 to 3 : none $(0),<5$ (1), 5-10 (2), and $>10$ (3). Mann-Whitney $U$ tests were used for comparisons between active and abandoned sites.

\section{Results}

\section{Distribution and general habitat of colonies}

We examined 18 bee-eater breeding colony sites, all were on vertical slopes with horizontal nest tunnels, of various sizes (3-200 individuals) in 2002 (Figure 1). The minimum combined breeding population was estimated at 822 individuals. Other colonies probably exist on the island, especially in coastal dune areas not searched due to the presence of landmines. Most colonies (16) were found in sandy loam ( $74 \%$ of all individuals) with the only exceptions being colony $\mathrm{D}$, the island's largest, and colony $\mathrm{C}$ which both used sandy clay loam (totalling $26 \%$ of all individuals). No colony was built in clay loam, which is distributed primarily on the west side of the island.

In terms of the land use patterns, 495 (60\%) individuals associated with nine colonies (A, $\mathrm{B}, \mathrm{F}, \mathrm{N}, \mathrm{O}, \mathrm{P}, \mathrm{S}, \mathrm{Y}, \mathrm{Z}$ ) were found using beach sand dunes, 221 (27\%) individuals associated with four colonies were using either man-made sand piles $(T, U)$ or gorges with substantial erosion (C, D) located in open areas surrounded by forested habitats, and 106 $(13 \%)$ individuals belonging to five colonies (I, L, V, W, X) were found using man-made sand piles in agricultural areas.

Two abandoned colony sites $(\mathrm{G}, \mathrm{H})$ were located in the centre of the island in an open area surrounded by forested habitat. These colonies were abandoned in 1998. The cliff faces associated with these sites were originally created by mining for china clay.

\section{Soil}

Blue-tailed bee-eaters established their breeding colonies preferentially in sandy and sandy clay loam. They avoided clay loam. Soil pressure, density, and moisture were all significantly different among different soil types (Kruskal-Wallis test $=20.66,6.88,7.26$, 
respectively, $P<0.05$ ), with clay loam showing significant differences from sandy clay loam in each parameter (Dunn multiple comparison, $P<0.05$, Table I). All soil types were slightly acidic, but clay loam was significantly more so than sandy clay loam (Dunn multiple comparison, $P<0.05$, Table I).

\section{Vegetation}

Active cavities had shorter vegetation directly within $5 \mathrm{~m}$ than did cavities used in previous years within the same colony (colony X: active, $n=10,2.6 \pm 0.5 \mathrm{~cm}$; abandoned, $n=13$, $16.9 \pm 1.6 \mathrm{~cm} ; U=124.5, P=0.0002)$ but the same pattern was not statistically significant in a comparison of a newly established colony (colony L, $n=3,9.0 \pm 4.0 \mathrm{~cm}$ ) and a recently abandoned colony (colony $M, n=13,25.1 \pm 3.4 \mathrm{~cm} ; U=31, P=0.122$ ) (Figure 2). These results support our general observation that bee-eaters avoid nesting near tall vegetation.

The average distance between 20 active nest cavities and the nearest vegetation $(81.8 \pm 14.7 \mathrm{~cm})$ was significantly greater than that of 20 random points $(35.0 \pm 10.0 \mathrm{~cm}$, $\left.t_{19}=2.6, P=0.012\right)$. These results again indicate that bee-eaters preferred to dig nest cavities away from vegetation.

\section{Water chemistry and dragonfly diversity}

Statistical analyses of water chemistry and dragonfly data were not feasible due to small samples, however, clear differences were apparent between used and abandoned sites. The water chemistry values for EC, $\mathrm{NTU}, \mathrm{BOD}_{5}, \mathrm{NO}_{3}{ }^{-}-\mathrm{N}, \mathrm{Cl}^{-}, \mathrm{SO}_{4}{ }^{2-}, \mathrm{Ca}, \mathrm{Mg}, \mathrm{Na}$, K, and chlorophyll $a$ were all greater for ponds near used colonies than those near abandoned sites (Table II). Colony L, an active colony, had the highest dragonfly species richness (13 species). Overall, the used colonies had more dragonfly species and a greater abundance of individuals than the abandoned ones (Table III).

\section{Discussion}

This study demonstrated that blue-tailed bee-eater colonies were distributed non-randomly on Kinmen Island. They preferred sandy soils, the same as European bee-eaters (M. apiaster Linnaeus) (White et al. 1978; Kossenko and Fry 1998), blue-cheeked bee-eaters (M. persicus Pallas) (Kossenko and Fry 1998), and rainbow bee-eaters (M. ornatus Latham) (Boland 2004), which were associated primarily with the beaches around the island and interior habitats of the eastern half of the island. Two colonies were found associated with sandy clay loam in the interior of the island. Colonies were associated with open habitats,

Table I. Soil attributes at sites unused and used for blue-tailed bee-eater colonies.

\begin{tabular}{lcccccc}
\hline & \multicolumn{2}{c}{ Unused } & & \multicolumn{3}{c}{ Used } \\
\cline { 2 - 2 } Item/soil sample & Clay loam $(n=3)$ & & Sandy loam $(n=3)$ & Sandy clay loam $(n=3)$ & $P$ value \\
\hline Soil pressure $\left(\mathrm{g} \mathrm{cm}^{-2}\right)$ & $120.0 \pm 19.0^{\mathrm{a}}(n=10)$ & & $60.0 \pm 23.5^{\mathrm{b}}(n=20)$ & $106.6 \pm 24.2^{\mathrm{a}}(n=5)$ & $<0.001$ \\
Soil density $\left(\mathrm{g} \mathrm{cm}^{-2}\right)$ & $1.62 \pm 0.01^{\mathrm{a}}$ & & $1.53 \pm 0.01^{\mathrm{b}}$ & $1.55 \pm 0.01^{\mathrm{ab}}$ & 0.032 \\
Soil moisture (\%) & $3.5 \pm 0.7^{\mathrm{a}}$ & & $0.7 \pm 0.4^{\mathrm{b}}$ & $2.5 \pm 0.2^{\mathrm{ab}}$ & 0.027 \\
Soil pH & $4.5 \pm 0.2^{\mathrm{a}}$ & & $5.0 \pm 0.2^{\mathrm{ab}}$ & $5.7 \pm 0.5^{\mathrm{b}}$ & 0.027 \\
\hline
\end{tabular}

Kruskal-Wallis test with Dunn multiple comparisons. Values within a row followed by different letters are significantly different $(P<0.05)$. 


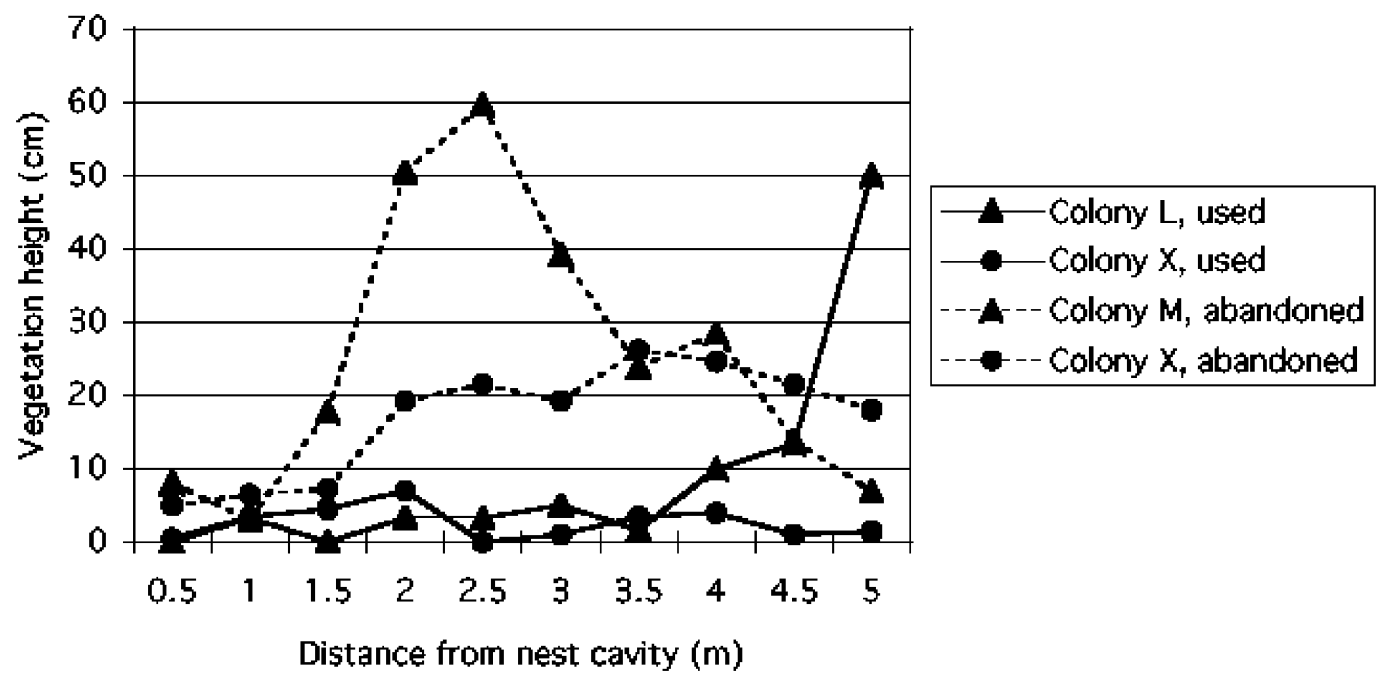

Figure 2. Vegetation height profile comparisons between used (solid lines) and abandoned (dashed lines) bluetailed bee-eater nest cavities within colony $(\mathrm{X})$ and between colonies ( $\mathrm{L}$ and $\mathrm{M}$ ).

which were used for foraging, but these open tracts were sometimes surrounded by forested habitat. Habitat types associated with colonies can all be categorised as 'disturbed' habitats (naturally or anthropogenically) and included wind-blown coastal dunes, eroded gorges, plus agricultural and construction sites with man-made sand piles. This apparent preference for disturbed habitats is seen in many Merops bee-eater species and is probably a partial explanation for the fact that no species in the genus is of immediate conservation concern (Fry 2001).

Table II. Water chemistries of water bodies near abandoned and used blue-tailed bee-eater colonies.

\begin{tabular}{|c|c|c|c|c|c|c|c|c|}
\hline \multirow[b]{2}{*}{ Item } & \multicolumn{3}{|c|}{ Abandoned } & \multicolumn{5}{|c|}{ Used } \\
\hline & G & $\mathrm{H}$ & Mean & $\mathrm{L}$ & $\mathrm{V}$ & W & $\mathrm{X}$ & Mean \\
\hline Water temperature $\left({ }^{\circ} \mathrm{C}\right)$ & 19.7 & 18.9 & 19.30 & 19.4 & 19.8 & 20.3 & 20.0 & 19.88 \\
\hline $\mathrm{EC}\left(\mathrm{S} \mathrm{cm}^{-1}\right)$ & 61.0 & 102.8 & 81.90 & 222.0 & 258.0 & 248.0 & 179.5 & 226.88 \\
\hline $\mathrm{pH}$ & 4.99 & 4.70 & 4.85 & 6.57 & 4.03 & 7.62 & 6.61 & 6.21 \\
\hline $\mathrm{DO}\left(\mathrm{mgl}^{-1}\right)$ & 8.80 & 8.80 & 8.80 & 6.60 & 8.70 & 9.80 & 8.30 & 8.35 \\
\hline $\mathrm{NTU}\left(\mathrm{mg} \mathrm{SiO}_{2} \mathrm{l}^{-1}\right)$ & 9.35 & 6.06 & 7.71 & 24.80 & 13.10 & 41.30 & 25.80 & 26.25 \\
\hline $\mathrm{BOD}_{5}\left(\mathrm{mgl}^{-1}\right)$ & 2.16 & 1.15 & 1.66 & 4.08 & 3.67 & 8.69 & 4.47 & 5.23 \\
\hline $\mathrm{NO}_{3}{ }^{-}-\mathrm{N}\left(\mathrm{mgl}^{-1}\right)$ & 0.06 & 0.01 & 0.04 & 0.29 & 0.19 & 0.23 & 0.14 & 0.21 \\
\hline $\mathrm{Cl}^{-}\left(\mathrm{mgl}^{-1}\right)$ & 9.22 & 11.70 & 10.46 & 29.07 & 31.91 & 21.27 & 23.75 & 26.50 \\
\hline $\mathrm{SO}_{4}{ }^{2-}\left(\mathrm{mg} \mathrm{l}^{-1}\right)$ & 8.27 & 7.14 & 7.71 & 16.41 & 36.13 & 18.74 & 14.76 & 21.51 \\
\hline $\mathrm{NH}_{4}^{+}\left(\mathrm{mgl}^{-1}\right)$ & 0.13 & 0.05 & 0.09 & 0.21 & 0.10 & 0.12 & 0.10 & 0.13 \\
\hline $\mathrm{HCO}_{3}{ }^{-}\left(\mathrm{mgl}^{-1}\right)$ & 1.01 & 1.01 & 1.01 & 23.23 & 0.00 & 40.40 & 6.06 & 17.42 \\
\hline $\mathrm{Ca}\left(\mathrm{mgl}^{-1}\right)$ & 1.36 & 1.71 & 1.54 & 8.37 & 2.83 & 14.34 & 2.54 & 7.02 \\
\hline $\operatorname{Mg}\left(\mathrm{mgl}^{-1}\right)$ & 0.86 & 1.30 & 1.08 & 4.17 & 3.83 & 4.13 & 3.61 & 3.94 \\
\hline $\mathrm{Na}\left(\mathrm{mgl}^{-1}\right)$ & 3.94 & 8.39 & 6.17 & 14.75 & 17.00 & 15.57 & 15.95 & 15.82 \\
\hline $\mathrm{K}\left(\mathrm{mgl}^{-1}\right)$ & 1.08 & 1.17 & 1.13 & 3.03 & 3.73 & 4.93 & 3.54 & 3.81 \\
\hline $\begin{array}{l}\text { Chlorophyll } a \\
\quad\left(\mathrm{mg} \mathrm{m}^{-3}\right)\end{array}$ & 0.000 & 0.001 & 0.0005 & 0.008 & 0.021 & 0.031 & 0.016 & 0.02 \\
\hline
\end{tabular}


Table III. The occurrence of dragonfly species at water bodies near abandoned and used blue-tailed bee-eater colonies.

\begin{tabular}{|c|c|c|c|c|c|c|}
\hline \multirow[b]{2}{*}{ Species name } & \multicolumn{2}{|c|}{ Abandoned } & \multicolumn{4}{|c|}{ Used } \\
\hline & $\mathrm{G}$ & $\mathrm{H}$ & $\mathrm{L}$ & $\mathrm{V}$ & W & $\mathrm{X}$ \\
\hline Ishnura senegalensis & & & $\star$ & $\star$ & $\star$ & $\star$ \\
\hline Ceriagrion latericium & & & $\star$ & & & \\
\hline Sinitinogomphus clavatus & & & $\star$ & & & \\
\hline Ictinogomphus rapax & & & $\star$ & & $\star$ & $\star$ \\
\hline Anax parthnope & & & $\star$ & & & \\
\hline Acisoma panorpodes & & & $\star$ & & & \\
\hline Brachythemis contaminata & & & $\star$ & $\star$ & $\star$ & * \\
\hline Diplacodes trivialis & & & $\star$ & $\star$ & $\star$ & $\star$ \\
\hline Pantala flvavescens & $\star$ & $\star$ & $\star$ & $\star$ & $\star$ & $\star$ \\
\hline Pseudothemis zonata & & & $\star$ & $\star$ & $\star$ & $\star$ \\
\hline Orthetrum Sabina & $\star$ & $\star$ & $\star$ & $\star$ & $\star$ & $\star$ \\
\hline Brachydiplax chalybea & & & $\star$ & & & $\star$ \\
\hline Rhyothemis variegate & & & $\star$ & $\star$ & $\star$ & $\star$ \\
\hline Number of species & 2 & 2 & 13 & 7 & 8 & 9 \\
\hline Abundance of dragonfly & 1 & 1 & 3 & 3 & 3 & 3 \\
\hline
\end{tabular}

Blue-tailed bee-eaters prefer to nest in sandy soils (also see Yuan et al, in press). Sandy soils have lower soil pressure, density and moisture than more clay-rich soils. Sandy soils also have high percentages of sand with reduced amounts of silt and clay (Yuan et al, in press). Sandy soils probably provided for faster and easier excavation of nest cavities, and better drainage (Brooks and Davis 1987). With high porosity, nest tunnels constructed with sandy soils would also have better ventilation, which was important to diffuse gases to maintain a tolerable level of $\mathrm{O}_{2}$ and $\mathrm{CO}_{2}$ in the nest cavities (White et al. 1978). Heneberg (2001, 2003, 2004) and Heneberg and Simecek (2004) conducted a series of soil particle size analyses on cliff-nesting sand martins (Riparia riparia Linnaeus), Euroasian kingfishers (Alcedo atthis Linnaeus), and European bee-eaters. They found the particle size of soil composing the cliff would influence which species nested there and explained why certain species were not co-nesting. Soil particle size could also affect the structure of the nest tunnel: Heneberg (2003) found the proportion of small particles in the soil was positively correlated with nest tunnel length which, in turn, positively affected sand martin breeding success. Further study on soil particle size in blue-tailed bee-eater nest sites would be useful for the Kinmen National Park to establish new bee-eater nest colonies in locations readily viewable by the public, and will provide a better protection for this species from disturbance by increasing numbers of tourists outside the park boundary.

In this study, we found blue-tailed bee-eaters avoided placing nest cavities in areas with dense vegetation, and presumably abandoned colony sites when they became overgrown. Many bee-eater species have also been seen nesting on bare ground without much vegetation (White et al. 1978; Emlen 1990; Kossenko and Fry 1998; Boland 2004). Avoidance of vegetation explains blue-tailed bee-eaters' apparent preference for disturbed habitats as these sites have reduced vegetation before vegetation succession begins. Predation (primarily by snakes) is a constant threat to successful reproduction in this species and reduced vegetation at the colony probably facilitates detection of predators and increases the effectiveness of mobbing behaviour. Roots would also become obstacles to excavation of the nest cavity, which belted kingfishers (Megaceryle alcyon Linnaeus) also avoid (Brooks and Davis 1987). Water chemistry associated with nearby freshwater may 
also influence colony site selection in blue-tailed bee-eaters. They may prefer colony sites near water bodies showing water chemistries indicative of more biological productivity, especially with regard to dragonfly species richness and abundance.

Availability of appropriate colony sites will influence coloniality in this species but numerous apparently viable sites are not used on Kinmen Island. In fact, it is clear that blue-tailed bee-eaters (either as individuals or colonies) are not evenly distributed among appropriate nesting habitats on the island, as would be expected under conditions of an ideal free distribution. Instead, over-clumping of bee-eaters at certain colony sites is evident and could be explained in several ways (Danchin and Wagner 1997). Existing colonies may represent traditional sites where successful breeders return year after year. Novice and previously unsuccessful breeders may be attracted to these locations primarily due to the presence of their successful conspecifics (the traditional aggregation, or TAG, hypothesis; Shields et al. 1988). Blue-tailed bee-eaters do show considerable colony philopatry. When individuals change locations, for example when vegetation becomes too dense, they typically relocate to the nearest alternative colony (H.-W. Yuan et al., unpublished data). Future studies will investigate how individual blue-tailed bee-eaters use information concerning both habitat (variables identified in this study) and behavioural (i.e. late season sampling of conspecific breeding success, quality of potential mates, and extra-pair mates; Danchin and Wagner 1997) variation to choose among potential colonial and solitary nesting sites.

\section{Acknowledgements}

We thank P. J. Hayward and two anonymous reviewers for valuable comments on a draft of our manuscript. We thank the staff of Kinmen National Park for their considerable support and encouragement of our studies. S.-Y. Yang and J.-C. Wang provided much appreciated assistance with water analyses, and Y.-P. Wang with tables and figures. This research was supported by grants from Kinmen National Park and Council of Agriculture, Taiwan, to H.-W. Yuan and a faculty research grant to D. B. Burt by the Stephen F. Austin State University Research Council.

\section{References}

Block WM, Brennan LA. 1993. The habitat concept in ornithology: theory and applications. Current Ornithology $11: 35-91$.

Boland CRJ. 2004. Breeding biology of Rainbow Bee-eaters (Merops ornatus): a migratory, colonial, cooperative bird. Auk 121:811-823.

Brooks RP, Davis WJ. 1987. Habitat selection by breeding Belted Kingfishers (Ceryle alcyon). American Midland Naturalist 117:63-70.

Burt DB. 2002. Social and breeding biology of bee-eaters in Thailand. Wilson Bulletin 114:275-279.

Danchin E, Boulinier T, Massot M. 1998. Conspecific reproductive success and breeding habitat selection: implications for the study of coloniality. Ecology 79:2415-2428.

Danchin E, Wagner RH. 1997. The evolution of coloniality: the emergence of new perspectives. Trends in Ecology and Evolution 12:342-347.

Emlen ST. 1990. White-fronted Bee-eaters: helping in a colonially nesting species. In: Stacey PB, Koening WD, editors. Cooperative breeding in birds: long-term studies of ecology and behavior. Cambridge: Cambridge University Press. p 489-526.

Forsman JT, Monkkonen M, Helle P, Inkeroinen J. 1998. Heterospecific attraction and food resources in migrants' breeding patch selection in northern boreal forest. Oecologia 115:278-286.

Fretwell SD, Lucas HL. 1970. On territorial behavior and other factors influencing habitat distributions in birds. Acta Biotheoretica 19:16-36. 
Fry CH. 2001. Family Meropidae (Bee-eaters). In: del Hoyo J, Elliott A, Sargatal J, editors. Handbook of the birds of the world. Volume 6. Barcelona: Lynx Edicions. p 286-341.

Grinnell J. 1917. Field tests of theories concerning distributional control. American Naturalist 51:115-128.

Heneberg P. 2001. Size of sand grains as a significant factor affecting the nesting of bank swallows (Riparia riparia). Biologia 56:205-210.

Heneberg P. 2003. Soil particle composition affects the physical characteristics of Sand Martin Riparia riparia holes. Ibis 145:392-399.

Heneberg P. 2004. Soil particle composition of Euroasian kingfishers' (Alcedo atthis) nest sites. Acta Zoologica Academiae Scientiarum Hungaricae 50:185-193.

Heneberg P, Simecek K. 2004. Nesting of European bee-eaters (Merops apiaster) in Central Europe depends on the soil characteristics of nest sites. Biologia 59:205-211.

Johnson DH. 1980. The comparison of usage and availability measurements for evaluating resource preference. Ecology 61:65-71.

Jones J. 2001. Habitat selection studies in avian ecology: a critical review. Auk 118:557-562.

Kendeigh SC. 1945. Community selection in birds on the Heldenberg Plateau of New York. Auk 62:418-436.

Kossenko SM, Fry CH. 1998. Competition and coexistence of the European Bee-eater Merops apiaster and the Blue-cheeked Bee-eater Merops persicus in Asia. Ibis 140:2-13.

Kuo CM, Chen ZS. 2002. Soil analyses and vegetation adaptations in Kinmen National Park. Technical report. Taiwan: Kinmen National Park. (Chi with Eng abstract).

Martin TE. 1993. Nest predation and nest sites: new perspectives on old patterns. BioScience 43:523-532.

McCollin D. 1998. Forest edges and habitat selection in birds: a functional approach. Ecography 21:247-260.

Morris DW. 1987. Ecological scale and habitat use. Ecology 68:362-369.

Orians GH, Wittenberger JF. 1991. Spatial and temporal scales in habitat selection. American Naturalist 137(Suppl):29-49.

Petit LJ, Petit DR. 1996. Factors governing habitat selection by Prothonotary warblers: field tests of the FretwellLucas models. Ecological Monographs 66:367-387.

Shields WM, Crook JR, Hebblethwaite ML, Wiles-Ehmann SS. 1988. Ideal free coloniality in the swallows. In: Slobodchikoff CN, editor. The ecology of social behavior. New York: Academic Press. p 189-228.

Wang LP. 2003. Breeding habitat selection and breeding biology of Blue-tailed Bee-eaters (Merops philipennus) on Kinmen Island [MS thesis]. Taipei: National Taiwan University. (Chi with Eng abstract).

White FN, Bartholomew GA, Kinney JL. 1978. Physiological and ecological correlates of tunnel nesting in the European Bee-eater, Merops apiaster. Physiological Zoology 51:140-154.

Yuan HW, Wang MK, Chang WL, Wang LP, Chen YM, Chiou CR. Soil composition affects the nesting behavior of blue-tailed bee-eaters (Merops philippinus) on Kinmen Island. Ecological Research. In press (DOI: 10.1007/s11284-006-0183-9). 